\title{
Parody as Translation: Ibsen's new woman in the pages of Punch
}

\section{REBECCA FLYNN}

\begin{abstract}
"Parody as Translation: Ibsen's new woman in the pages of Punch" examines four comic parodies of Ibsen written by Thomas Antsey Guthrie, a British journalist and humourist also known as F. Antsey. The plays examined include parodies of Rosmersholm, A Doll's House, Hedda Gabler, and The Master Builder - comically abbreviated renditions of Ibsen originals that featured striking new women characters. Reading these parodies as responses to their originals, I examine what happens to the new woman character when she is subjected to comic parodic treatment. Although the parodies do not directly focus on the alteration of these key female characters, I argue that Antsey's parodic critique of Ibsenian dramaturgical mechanics, conventions, and tropes indirectly impacted their representation, transforming them from tragic heroines to comic figures and raising further questions about the relationship between gender and comedy. In each parody, the psychological complexity of the new woman character is compromised through Antsey's alteration of one or more of her key purposes within Ibsen's text. Overall, I argue that the reassessment and reinterpretation of these key Norwegian texts can be viewed as a mode of transition between Ibsen and those impacted and influenced by him, providing a cultural medium or "buffer" that helped connect the notably "serious" Scandinavian playwright with British audiences.
\end{abstract}

\section{KEYWORDS}

New woman, parody, Ibsen, humour, modern drama, British audiences 


\section{Parody as Translation: Ibsen's new woman in the pages of Punch ${ }^{1}$}

In 1891, George Bernard Shaw credited Henrik Ibsen with single-handedly defining the new woman. Shaw described this character as "an empowered and disillusioned female" who rejected "womanliness, her [duties] to her husband, children, society, the law, and to everyone but herself."2 This article focuses on the relationship between Ibsen's original plays and parody, and more specifically - what happens to the original text when this female character is removed from the confines of Ibsen's social problem plays and modern tragedies, and subjected to comic parodic treatment. Ibsen's representation of the new woman as an inherently serious, dramatic character at the centre of his realist social problem plays often drew parodists and satirists to his controversial work. In Britain, the most clever and popular of these parodies were those of British journalist and novelist Thomas Antsey Guthrie. His comic renditions of some of lbsen's best-known plays were initially published under the pseudonym F. Antsey as a series in Punch - a British weekly magazine of humour and satire. The plays parodied within the series included Rosmersholm, A Doll's House, Hedda Gabler, and The Wild Duck, appearing over a span of ten weeks in $1891 .^{3}$ Tracy C. Davis argues that these specific parodies were "probably the most amusing, topical, and indicative of the general perception of Ibsen in Late-Victorian England," adding, "they were popular, too."4

Antsey's reinterpretations of these key Norwegian texts can be viewed as a mode of translation between lbsen and audiences who were impacted and influenced by him. In her article "Pandemic and Performance: Ibsen and the Outbreak of Modernism," Katherine E. Kelly states that Antsey's parodies "domesticate[d] and familiarize[d] [lbsen's] Nordic exotica through the leveling

1. Thanks to Penny Farfan for her help with this article.

2. Shaw 1891, 43.

3. Andre Gailani, "Re: Inquiry from Rebecca Flynn," 3 November 2014.

4. Davis 1985, 88. 
tool of British humor." I argue that the major translation Antsey's parodies perform is the translation of Ibsen's "serious" new woman characters and stark realism into what could be considered a more approachable and digestible British "language". The parodist's purposeful application of comedy provided a necessary cultural buffer between the serious Scandinavian playwright and British audiences, serving as an effective method of translation. Using parodic "language" as a vehicle for mass accessibility, Antsey attempted through humour to bridge the theatrical and social gaps that existed between the playwright's place of origin and the readers of Punch, a British staple that "came to be viewed as the official point of view of the English, at home and around the world."6 Antsey's immensely popular parodies contributed to the discussion and debate of Ibsen's work even after it was staged, affording his plays and his new woman characters with an afterlife and a renewed relevancy for British audiences.

Giving context to the appearance of these parodies, Tracy C. Davis writes that in the early $1890 \mathrm{~s}$, translations of Ibsen were readily and inexpensively available, and Ibsenite producers [--] presented every one of the "Master's" plays from The Pillars of Society to The Master Builder in rapid and (depending on one's outlook) nauseous or delightful succession." While the onslaught of these productions prompted varied reactions from British citizens, it is interesting to note that the appearance of Antsey's parodies in Punch, a periodical publication rather than a staged production, represented not only a population of readers that had seen these productions first hand, but also a population who had only heard about them - likely through the controversial and often negative reviews. Davis adds that, generally speaking, "Outspoken anti-lbsenites, as well as less decided partisans, used humor to express the frustration that arose when their efforts to ignore, deride, or curse lbsen failed to prevent new productions or silence the Ibsenites." I argue that while Antsey's parodies undoubtedly use humour as a tool, the goal of his parodies is not to dismiss Ibsen's ideas, but rather to deliver his content to an audience who had, in many ways, already made up their mind about the "serious" Scandinavian playwright. Antsey exists as a bit of an outlier compared to other British parodists of Ibsen. Davis states that, in Antsey's collection, "ridicule, rather than sarcasm, was used, and so everyone could enjoy the truly absurd and preposterous dialogues and verses as a respite from the vicious
5. Kelly $2008,28$.
6. The Victorianist $2013,1$.
7. Davis $1985,87$.
8. Ibid. 
backbiting and intense debate." She adds that his "only purpose was to be humorous, and this he fulfilled." "Furthermore, it is likely that many readers of Punch were not regular theatregoers and were, instead, avid readers of humour and satire. Antsey grants these readers access to Ibsen's world of characters and ideas, translating them for those who were ill-prepared for the "foreign" theatrical conventions.

After appearing in the pages of Punch, the parodies were published as a separate collection in 1893 under the title Mr. Punch's Pocket Ibsen: A Collection of Some of the Master's Best Known Dramas. In this revised version, Antsey added a fifth piece that did not originally appear in Punch, a parody of Ibsen's The Master Builder called Pill-Doctor Herdal. The introduction to the independent collection describes the parodies as "condensed, revised and slightly rearranged" pieces "for the benefit of the earnest student."10 Antsey's take on Ibsen's dialogue and dramaturgical conventions ultimately impacted the representation of Ibsen's women characters. By altering the structure of each play, Antsey, albeit indirectly, diminished the psychological complexity of each new woman character, eliminating her key role within Ibsen's original text.

\section{DEFINING ANTSEY'S PARODY}

In order to properly assess what happens to Ibsen's text when it is subjected to Antsey's parodic treatment, it is imperative to supplement a comparison between both authors' works with a clear definition of parody itself. Regarding the basic function of the form, M. H. Abrams states that parody "imitates the serious materials and manner of a particular literary work, or the characteristic style of a particular author, or the stylistic and other features of a serious literary form, and applies them to a lowly or comically inappropriate subject."11 While definitions like Abrams' help to identify parody as a literary form, they tend to diminish the complexity of parody's form and function. In an attempt to remedy this misrepresentation, Linda Hutcheon offers a revised definition of the form that supports an informed understanding of the individual plays in Mr. Punch's Pocket Ibsen. Hutcheon broadly defines all parody as "repetition with critical difference."12 Moreover, she states that "parody is doubly coded in political terms: it both legitimizes and subverts that which it parodies."13 Clari-

9. Davis $1985,88$.

10. Antsey $1893,2$.

11. Abrams 1988, 18.

12. Hutcheon $2000,20$.

13. Hutcheon 1989, 106. 
fying and reaffirming the association of parody with socio-political impact, she adds that the form "inscribes as well as subverts." 14 Therefore, it is necessary to view Antsey's work as a re-presentation of Ibsen's original work with notable elements of critical difference. Furthermore, by employing parody, Antsey subverts or challenges Ibsen's ideas and conventions while simultaneously re-inscribing them for British audiences. Although Hutcheon's definition of parody does not require all parodic mediums to partake in the comic, Antsey's short plays are undoubtedly humourous. This shift in theatrical genre is undoubtedly the most striking element of critical difference as it becomes the vehicle for transcultural readings of Ibsen's work. Antsey's comic critique of Ibsenian dramaturgical mechanics, conventions, and tropes indirectly impact the representation of these women, transforming them from tragic heroines to comic figures and raising further questions about the relationship between gender, comedy, and the British reception of - and response to - Ibsen's work. Evaluating how Ibsen's text was specifically affected by it's re-situation within the comic form, this article analyzes four of Antsey's parodies that take a new woman figure as their central focus: Rosmersholm, Nora; or the Bird Cage, Hedda Gabler, and Pill-Doctor Herdal. ${ }^{15}$

\section{ROSMERSHOLM: "WHY SHOULD WE JUMP AT ALL?"}

The first parody to appear in Antsey's series is, like the original, titled Rosmersholm. Ibsen's version premiered in Britain in February of 1891, only a month before Antsey's parody was published in Punch. The proximity between the theatrical production and the appearance of the parody in print offers insight into Ibsen's immediate impact on the British stage and the amount of critical attention his plays received. It seems that, in general, parodists like Antsey were very quick to respond to these Ibsenian productions. Davis speaks about this succession of prompt reactions stating, "the first parody to be inspired by the lbsen movement appeared in 1889, only a week after Janet Achurch's debut as Nora at the Novelty Theatre."16 This specific production of Rosmersholm generated mixed reviews. Much of the criticism surrounding the British premiere concerned itself with "the nastiness of Re-

14. Hutcheon 1989,106 .

15. While The Wild Duck parody offers a comic critique of Ibsen's conventions, both the original text and the parody lack a strong new woman character. As the new woman and her relationship to comedy is the central focus of this article, the parody will be intentionally excluded.

16. Davis $1985,87$. 
becca's love for Rosmer" and "the absurdity of the double suicide."17

Antsey's parody significantly condenses Ibsen's plot, removing a great deal of the language, nuance, and subtext that distinguishes the original. Here, Antsey uses humour to help mainstream British readers digest Ibsen's apparent "disregard for stage conventions, [his] improbabilities in his plots, [and his] awkward and seemingly absurd dialogue."18 Maintaining, but abbreviating Ibsen's structure, Antsey provides four short acts that comically undermine Ibsen's controversial content and, as a result, the seriousness and complexity of his new woman figure, Rebecca. Davis lends contextualization to some of Antsey's intentions by stating that, at the time, "Champions of the mainstream conventional drama insisted that Ibsen could not possibly be taken seriously, and mimicked the techniques of the new drama, pointing out some of the absurdities barely submerged beneath the dull and prosaic dialogue."19 While Antsey does not dismiss Ibsen as a "serious" playwright, he seems to utilize many of the same conventions used by "anti-Ibsenite" satirists and parodists in order to appeal to a broader readership, one that - as mentioned previously - may not have seen Ibsen's plays but only heard about them through negative reviews. Thus, Antsey's comic approach actually seems to support Ibsen's ideas under the guise of dismissing them.

The Rosmersholm parody imitates the plot of the original work until the play's conclusion, at which point Rosmer and Rebecca's joint suicide is comically delayed by the appearance of a white horse. The obstruction prompts Rosmer to declare, "We can't be expected to jump off a footbridge which already has a White Horse on it. And if it comes to that, why should we jump at all?"20 A recurring image in Ibsen's version, the symbolic white horse of Rosmersholm is frequently "seen" by the characters after Beata's suicide. The animal represents the unresolved past and the haunting of the characters by traditional ideologies about sex, gender, and morality. In Ibsen's original conclusion, the horse "appears" before the pair's death, symbolizing the couple's inability to overcome past indiscretions. Here, Antsey substitutes the subtle poetry of Ibsen's white horse with the irony of physical comedy, transforming it from a metaphor into a physical barrier. Rebecca and Rosmer abort their suicide plans, eliminating the tragic poetic ending that signifies the pair's eternal union in Ibsen's version. In a way, the altered ending offers a sort of

17. Franc 1970, 36.

18. Davis 1985, 89.

19. Davis $1985,87$.

20. Antsey 1893, 33. 
perverse resolution where the significance of Beata's death - and the couple's guilt surrounding it - is completely undermined. Although Rebecca announces that the couple will revisit their suicide plan at a later time, the play closes without any guarantee that they will follow through. The abrupt and ridiculous ending - thwarted by the sudden materialization of one of Ibsen's most poetic symbols - is anti-climactic and lacks the catharsis that accompanies the duo's death in the original work. The revised ending removes Rebecca's internal struggle, enhancing the "nastiness" of her love for Rosmer. By removing her tragic dilemma, where Rebecca is torn between rebellion and convention, and by eliminating Ibsen's crucial exposition, which helps one understand her character's past and present, Antsey's comedy paints Rebecca as the kind of two-dimensional monster that early lbsen critics misread her as.

While the parody does not intentionally set out to rewrite Ibsen's new woman character - but is instead focussed on "translating" Ibsen's language and conventions - what is of interest in Antsey's Rosmersholm is the fact that the female protagonist remains physically present by the play's conclusion. While Antsey intended to undermine the seriousness of Ibsen's content, his altered comic ending indirectly allows the new woman character - and the greater social issues she represents - to "live on" both on and offstage. Since Rebecca survives Ibsen's original attempt to discard her, the reader is unable to dismiss her as a victim of tragedy or a fallen woman, and is instead confronted with the new woman's presence both within the play and within British society.

\section{NORA; OR, THE BIRD CAGE: A DOOR "UN-SLAMMED"}

The second parody in the series is Nora; or, the Bird Cage, Antsey's take on Ibsen's A Doll's House. The first notable British production of the play, a translation in its regular form, premiered in 1889 at the Novelty Theatre where Nora, played by Janet Achurch, made theatrical and social history. In her book Ibsen's Women, Joan Templeton writes that as a result of the play, "Ibsen was accused not merely of advocating the destruction of the family, and with it, morality itself, but of godless androgyny" whereby "women, in refusing to be compliant, were refusing to be women." 21 As the perceived "absurdity" of Nora's transition from obedient housewife to emancipated woman was arguably the main source of contention within the play's early reviews, it is unsurprising that Antsey's parody functions as a critical response to this 
opinion. ${ }^{22}$ In particular, the play's ending astounded British viewers, splitting audiences and critics alike. In reference to Ibsen's conclusion, writer and critic James Huneker noted: "That slammed door reverberated across the roof of the world," referring to how vastly Nora impacted the discussion of women and social responsibility in Britain and the rest of the world. ${ }^{23}$

As in his Rosmersholm parody, Antsey's altered conclusion is of particular interest in Nora; or, The Bird Cage. Immediately after Nora announces her departure, both literally and figuratively slamming the door on her former life, she returns. But before she leaves, the following dialogue takes place:

NORA: My eyes are opened, and I see my position with the eyes of Ibsen. I must go away at once, and begin to educate myself.

HELMER: May I ask how you are going to set about it?

NORA: Certainly. I shall begin - yes, I shall begin with a course of the Norwegian theatres. If that doesn't take the frivolity out of me, I don't really know what will!24

After lamenting for a moment, Torvald notices that his wife has returned: HELMER: What? Back already! Then you are educated?

NORA: No, Torvald, not yet. Only, you see, I found I had only threepence-halfpenny in my purse, and the Norwegian theatres are all closed at this hour and so I thought I wouldn't leave the cage till to-morrow - after breakfast." 25

Like Antsey's Rosmersholm, the parody concludes with the female protagonist's resolve to revisit her plans at a later time.

Nora's abrupt and comic un-emancipation - prompted by her inability to attend an Ibsen play that would have educated her about new womanhood wholly undermines the seriousness of her departure. With the aborted ending, Antsey mocks her seemingly drastic character shift, robbing her of the bold feminist significance she carries in Ibsen's version. As a result, the humourist

22. In a review of the 1889 production from The Daily Telegraph, Clement Scott famously wrote: "The baby wife, who has suddenly and miraculously developed into a thinking woman, leaves her home, breaks her marriage oath, refuses to forgive her husband, abandons her innocent children, and becomes absolutely inhuman, simply because she discovers her husband is an egotist and that she has been a petted little fool. [--] How it could ever be possible for any woman with the maternal instinct fully developed to desert her children because her pride was wounded, are points that may be very clear to the Ibsenites, but they require a considerable amount of argument in order to convince the common-sense playgoer". Egan 1972, 102.

23. Cunningham \& Reich 2009, 492.

24. Antsey 1893, 23.

25. Antsey 1893, 24. 
transforms the text from a serious social drama into a sort of makeshift romantic comedy. Her hasty return trivializes her determination to break away from the social conventions that once held her hostage. Within a matter of seconds, she reverts back to the position she was in at the beginning of the play - eating macaroons with her condescending husband. Departing from the stark realism of Ibsen's conclusion, Antsey's revised ending more accurately reflects traditional comedy's tendency to provide the romantic union (or in this case, reunion) of a man and a woman. ${ }^{26}$ The "re-marriage" of Nora and Torvald provides a major shift in theatrical genre, one that substitutes a comic resolution in place of Nora's transformation and emancipation.

As in his Rosmersholm parody, Antsey ignores Ibsen's tendency to focus on subtext and character psychology and instead inserts a logistical barrier between Nora and her impending freedom. Suggesting that the only way Nora can achieve a proper self-education is through a theatre-going experience with a new woman character like Ibsen's original Nora, Antsey simultaneously mocks Ibsenites while acknowledging the Norwegian's widespread influence on the British stage and in British society. However, what is of greater significance in Antsey's parody is how easily a seemingly minor roadblock dismantles Nora's quest for personal liberation. It seems that the parodist provides audiences with a sardonic answer to the lingering question at the end of Ibsen's A Doll's House - whether Nora will ever return. Here, the female protagonist's "serious" decision to abandon her former life is transformed into a joke, emphasizing Nora's lack of integrity in decision-making. Antsey also seems to be playing with a sort of circular logic, suggesting that in order for his Nora to become a new woman character, she must first see Ibsen's A Doll's House to learn how. The ease with which Nora abandons her own values suggests an anti-feminist reading of the parody, echoing early dramatic criticism that declared Nora's transition from passive housewife to new woman was wholly unrealistic. Antsey suggests that when faced with any minor form of adversity, Nora, the supposed "new woman" character, would quickly return to her former life. However, perhaps it is too simplistic to view the revised ending as being in direct conflict with Ibsen's original conclusion. Perhaps Nora's return is just Antsey's attempt at finishing lbsen's open-ended drama. It seems only realistic that Nora would, at some point, return home to her husband and children. Regardless, Antsey's comic ending seeks to participate in the evolution and continuation of Ibsen's texts by offering up an ending that disallows the disappearance of this important female character.

26. Frye $1981,141$. 
HEDDA GABLER: "THE COURAGE OF LIFE ONCE MORE!"

The third parody in Antsey's series is Hedda Gabler. The Ibsen original, translated by Edmund Gosse, was published in 1890 and performed in Britain in 1891 with Elizabeth Robins in the leading role. Robins' production was both controversial and highly successful - the longest run to that date of any lbsen play in London. ${ }^{27}$ While the production was responsible for recruiting of many new lbsenites, it also outraged several critics. Many of these critics attacked Ibsen's "unrealistic" portrayal of Hedda, accusing the Norwegian playwright of "willful obscurity on the grounds that a Hedda Gabler could not exist" and had "no counterpart in the real world."28 The play's early commentators "refused Hedda the status of woman because they found her unwomanly," referring to her as an "inhuman woman - a savage," calling her "atrocious and intolerable."29

Like the preceding parodies, Antsey's Hedda Gabler repeats and comically condenses Ibsen's plot until the play's conclusion where the General's pistol goes "wild," accidentally killing George, Thea, and Judge Brack. The accidental massacre renders Hedda's own death unnecessary, prompting her to abandon her suicide plans. ${ }^{30}$ In her final line, Hedda says:

I've been trying in there to shoot myself beautifully - but with General Gabler's pistol - [She lifts the table-cloth, then looks behind the stove and under the sofa.] What! The accounts of all those everlasting bores settled? Then my suicide becomes unnecessary. Yes, I feel the courage of life once more!"31

Through the use of a comic gag whereby the General's pistol unintentionally kills off all of Hedda's "problems," the female protagonist is indirectly transformed from a trapped woman into an emancipated woman. More important than the parody's translation of genre is its shift in theatrical style. While the comic conclusion subverts the original, the ridiculousness of the entire parody allows Hedda to appear as an empowered female character. Providing insight into Antsey's dramaturgical choices, Carlson states that "when women gain power in comedy, the world is somehow extraordinary."32 Existing outside of Ibsen's realistic world, Hedda suddenly regains power over her situation, taking agency as an emancipated woman. This parody is different from the

27. Gates 1985, 611.

28. Templeton 1997, 204.

29. Templeton 1997, 205.

30. Antsey 1893, 36.

31. Ibid.

32. Carlson1991, 18. 
preceding two because Hedda's abandonment of Ibsen's conclusion actually liberates her. Unlike his approach to Rebecca and Nora, Antsey trivializes the seriousness of Hedda's problems rather than her ability to achieve personal autonomy. While still thwarting an Ibsenian conclusion, he affords Hedda an entirely new situation and, unlike the aforementioned characters, freedom from the individuals and situations that bind her.

By eliminating crucial elements of subtext, which in Ibsen's original imply that Hedda's demons are internal ones, Antsey removes the inner conflict between conservative and rebellious mind frames - that helped audiences understand her character. As a result, the parody comically reduces the scope of her problems to the presence of other individuals. Her representation within Antsey's work is complex and in some ways contradictory. In Ibsen's version, Hedda's greatest personal desire is for freedom, a desire that is only truly attained in her suicide at the play's end. Antsey's text still "frees" her character, but in a different way. Antsey's version completely ignores the mental entrapment she feels and instead surmises that her struggle can be resolved through the elimination of other characters. Furthermore, Hedda's seemingly cold response to the sudden death of her peers paints her as a sort of "femme fatale" character, echoing early criticism that deemed her a heartless and unrealistic monster. By eliminating her husband, the blackmailing Judge, and Lövborg's widowed lover, she escapes a life controlled by others and becomes emancipated. Although it requires the marginalization and trivialization of her inner struggle, Hedda's life is spared in Antsey's parody, suggesting that she is free to live by her own terms. Ironically, Antsey's ridicule of Ibsen's commitment to psychological realism in Hedda Gabler is exactly what saves this female character from her tragic fate.

\section{PILL-DOCTOR HERDAL: MIMICKING "THE MASTER"}

The most interesting parody in the collection is Antsey's concluding piece, Pill-Doctor Herdal. The play is a satire of Ibsen's The Master Builder, which was originally published in 1892 and first performed in London in 1893. As Antsey prefaces at the beginning of the series, Pill-Doctor Herdal pays homage to the Norwegian playwright by attempting to write a new piece, albeit satirically, in the style of Ibsen himself: "The concluding piece, Pill-Doctor Herdal, is, as the observant reader will instantly perceive, rather a reverent attempt to tread in the footprints of the Norwegian dramatist, than a version of any actually existing masterpiece. The author is conscious that his imitation is painfully lacking in the mysterious obscurity of the original, that the vein of 
allegorical symbolism is thinner throughout than it should be, and that the characters are not nearly so mad as persons invariably are in real life - but these are the faults inevitable to a prentice hand, and he trusts that due allowances may be made for them by the critical." ${ }^{33}$ Antsey makes it clear to his readership that the relationship between original and parody is respectful and not spiteful, even referring to lbsen's plays as "masterpieces".

Pill-Doctor Herdal is not a re-written version of The Master Builder but is actually a sequel, taking place years after Ibsen's conclusion. Antsey's plot begins ten years after the death of Solness, with his widowed wife Aline now married to Dr. Herdal. The couple discusses the history of Hilde Wangel and her relationship to Aline's late husband. The former Mrs. Solness expresses concern that she will return and that Herdal will suffer the same fate as Halvard. Herdal eases his wife's mind by telling her that Hilde is likely contained in "some sanatorium." 34 Soon enough, however, Hilde appears and informs Dr. Herdal that "she has come to make use" of him (49). ${ }^{35}$ Over the course of the second act, Hilde reveals that she has spent time with Kaia and Ragnar Brovik, secondary characters and love interests from Ibsen's The Master Builder. She tells Herdal that she encouraged Ragnar, an architect, to build houses with steeples, sending him into bankruptcy before fleeing. Hilde then goes on to reveal that she also spent time with George Tesman and his wife Thea, helping Tesman with his book. She adds that Thea became mad with jealousy, causing Tesman to shoot himself "un-beautifully." 36 Hilde then describes how she went to Rosmersholm where she met Rector Kroll. While there, she persuaded him to ride on the white horse, but because he had never ridden one before, he fell off into the mill-race and drowned.

After recounting her travels, Hilde mentions that she has heard Dr. Herdal is afraid of swallowing his own pills, just as Solness was afraid to climb his own buildings. She persuades him to overcome his fears, telling him to make a beautiful powder of poisons and eat it. He finally consents but is saved by his new bookkeeper - who has replaced all of the poison jars with chalk. In the most interesting aspect of this parody, the bookkeeper is actually revealed to be Torvald Helmer. He then turns to Hilde, whom he addresses as Nora, and says: "Surely, Nora, your education is complete at last - you have gained the experience you needed?" Hilde/Nora then responds: "Yes, Torvald, you're right enough there. I have thought things out for myself, and have got clear

33. Antsey $1893,2$.

34. Antsey $1893,48$.

35. Antsey 1893, 49.

36. Antsey 1893, 51. 
about them. And I have quite made up my mind that Society and the Law are all wrong, and that I am right." 37 Pill-Doctor Herdal concludes with Nora's return to Torvald and home.

Pill-Doctor Herdal reassesses not only Ibsen's The Master Builder, but Hedda Gabler, Rosmersholm, and A Doll's House as well. Hilde's retelling of past events offers insight into Antsey's representation of all of these new women characters. She speaks of encounters with Tesman and Thea, the former husband and friend of Hedda Gabler, as well Rector Kroll, Beata's brother from Rosmersholm. In both instances, the key female protagonists are notably absent. Although, in Ibsen's versions, both Rebecca and Hedda commit suicide, their absence in this context is suggestive of a greater meaning - that Rebecca, Hedda, and Hilde are one. The revelation that Antsey's Hilde Wangel is actually Nora Helmer solidifies this theory - all of Ibsen's new women characters are interchangeable. Antsey's "new woman" character is no specific, individual woman, but is rather a female archetype that can be recycled and reinserted into each individual play.

Nora's second return to Helmer - in addition to her homecoming at the end of Nora; or, The Bird Cage - where she claims to have "completed" her education implies that when sprung from her domestic situation, the "emancipated" woman will inevitably transform into a sort of femme fatale character, causing the demise of the men she encounters. This idea supports stereotypes that painted feminist figures as one-dimensional, "man-hating" individuals. Finally, Nora's lasting return to her family suggests a sort of "rehabilitation" for these aspiring new women characters. Each woman housed within Nora - is resituated in her private, domestic sphere by the end of Antsey's collection. In this final conclusion, the parodist mocks Ibsen's idea of female liberation, suggesting that although these women achieve brief moments of autonomy, the experience is fleeting.

Although the new woman is subverted or challenged through comedy, Antsey's collection paradoxically translates and re-inscribes her, reinforcing her impact on the modern British stage. While comedy is used as the chosen medium, the new woman and her legacy is the message that is left with British readers. Hutcheon writes that in most cases, modern parody functions not as a form of mockery but as a "respectful homage" to the original text. She adds that the intent of the parodist is not to "copy, but to recontextualize, to synthesize, to rework conventions - and in a respectful manner." 38 While the pseu-

37. Antsey $1893,59$.

38. Hutcheon 1989, 33. 
donym "F. Antsey" is often thought to be a play on the word "fantasy," 39 the author's alias can also be linked to the British slang term "fancy": "a desire or liking for." 40 The obvious parallel is suggestive of Antsey's admiration rather than distaste for Ibsen and his female heroines, a sentiment that is expressed in his description of himself in Punch as a "harmless Ibsenite." 41 It seems that in many ways Antsey's work represents a major turn in the reception of Ibsen in England. While his comic parodies may - on the surface - seem indicative of mockery or dismissal, Antsey's earnest attempt to emulate the modern playwright is ultimately a sign of respect for his work. Davis states that "despite the lingering impression that some of Ibsen's techniques were strange and some of his notions morally reprehensible, the exemplary performances given by a few Ibsenite actors and the impression of credibility and power that they instilled in audience members of all persuasions were effective causes of change." 42 The appearance of these parodies in the popular press also signals this changing appeal in the appreciation of Ibsen from smaller groups of critics and other intellectuals into mainstream culture. Antsey's translation is a sort of ode to Ibsen's influence in Britain, offering a medium and "language" that allowed Ibsen's work to evolve both culturally and socially. This idea of parody as a means for social evolution and literary continuity is further reflected in Hutcheon's statement that "perhaps parodists only hurry up what is a natural procedure, the changing of aesthetic forms through time." 43 Antsey's parodies exist as a part of a natural theatrical progression, making lbsen's work more accessible to British readers of the time period while participating in the ever-evolving dialogue about the playwright's work and its lasting legacy.

39. The Victorianist 2013, 1.

40. "Fancy," Oxford English Dictionary, Oxford University Press, Oxford, 2005. accessed 7 January 2015.

41. Franc 1970, 122.42. Davis 1985, 100.

43. Hutcheon 1989, 35. 


\section{References}

Abrams, M. H. 1988. A Glossary of Literary Terms. Florida: Holt, Reinhart, and Winston.

"'A Loud, Mocking Clamour of Noise...' Punch Or: The London Charivari: A Cultural Treasure Trove" in The Victorianist, 2013.

Antsey, F. 1893. Mr. Punch's Pocket Ibsen: A Collection of Some of the Master's Best-Known Dramas Condensed, Revised, and Slightly Rearranged for the Benefit of the Earnest Student. New York: Macmillan.

Carlson, Susan. 1991. Women and Comedy: Rewriting the British Theatrical Tradition. Michigan: University of Michigan Press.

Cunningham \& Lawrence \& Reich, John J. 2009. Culture and Values, Volume II: A Survey of the Humanities with Readings. Boston: Cengage Learning.

Davis, Tracy C. 1985. "Spoofing 'The Master': Parodies and Burlesques of Ibsen on the English Stage and in the Popular Press" in Nineteenth Century Theatre Research, vol. 13 no. 2, 1985.

Egan, Michael. 1972. Ibsen: The Critical Heritage. London: Routledge.

Franc, Miriam Alice. 1970. Ibsen in England. Folcroft: Folcroft Press.

Frye, Northrop. 1981. "The Mythos of Spring: Comedy" in Comedy: Meaning and Form. New York: Harper and Row.

Gates, Joanne. 1985. "Elizabeth Robins and the 1891 Production of Hedda Gabler" in Modern Drama, vol. 28 no. 4, 1985.

Hutcheon, Linda. 2000. A Theory of Parody: The Teachings of TwentiethCentury Art Forms. Urbana: University of Illinois Press.

Kelly, Katherine E. 2008. "Pandemic and Performance: Ibsen and the Outbreak of Modernism" in South Central Review, vol. 25 no. 1, 2008.

Shaw, Bernard. 1891. The Quintessence of Ibsenism. Boston: B. R. Tucker. Templeton, Joan. 1997. Ibsen's Women, Cambridge: Cambridge University Press.

\section{AUTHOR}

Rebecca Flynn is a Master of Arts Candidate in Gender Studies and Feminist Research at McMaster University in Hamilton, Ontario, Canada. She also holds a Master of Fine Arts in Theatre Studies from the University of Calgary and a Bachelor of Arts (Honours) in Drama and English Language and Literature from Queen's University. 